\title{
Influence of Jasmonic Acid and Chlorpropham Treatments on Sprouting, Quality and Storability of Potato Tubers during Cold Storage
}

\author{
M. S. Dhaif Allah ${ }^{1,2}$, F. I. El-Adgham ${ }^{1}$, S. M. El-Araby ${ }^{1}$, I. M. Ghoneim ${ }^{1}$ \\ ${ }^{1}$ Department of Vegetable Crops, Faculty of Agriculture, Alexandria University, Alexandria, Egypt. \\ ${ }^{2}$ Department of Plant Production, Faculty of Agriculture and Veterinary Medicine, Thamar University, \\ Thamar, Yemen.
}

\begin{abstract}
The present investigation was carried out on Diamant potato tubers (Solanum tuberosum L.), harvested at their commercial maturity stage (May, 2017) in a private farm at Kom Hamada Behira Governorate, Egypt. The selection of tubers was based on size, absence of physical injuries, mechanical damage and disease infection. Tubers were packed in net plastic boxes ( $15 \mathrm{~kg} /$ box), and were surface-disinfected by dipping in $2 \%$ sodium hypochlorite for $2-4$ mins, then rinsed with tap water and air-dried. Potato tubers were immersed in solutions containing chlorpropham (CIPC) at 0, 50, 75 and $100 \mathrm{ppm}$ and jasmonic acid (JA) at $0,0.001,0.01$ and $0.1 \mathrm{mM} / \mathrm{L}$, either alone or in combinations for 20 minutes and then were cured in the dark for one week at $20^{\circ} \mathrm{C}$ and $75 \% \mathrm{RH}$. After curing, the tubers were placed in the dark cold storage room for long-term storage ( 140 days) at $10 \pm 1{ }^{\circ} \mathrm{C}$ and $85 \pm 5 \%$ relative humidity (RH). Treatments were distributed in design with three replicates for each treatment (one replicate $=$ one box of $15 \mathrm{~kg}$ tubers).

Tuber's firmness, dry matter, starch, acidity and ascorbic acid increased, while SSC and total sugars decreased with increasing concentration of CIPC. Chlorpropham at the concentration of $75 \mathrm{ppm}$ of decreased the weight loss, decay and sprouting percent during cold storage or after removal from cold storage and kept at ambient temperature as compared with 50 or $100 \mathrm{ppm}$ and control. Furthermore, the storability and shelf life of potato tubers have been extended significantly with $75 \mathrm{ppm}$ in both the storage temperature conditions. Likewise, applied of jasmonic acid at rate of 0.01 $\mathrm{mM} \mathrm{JA} / \mathrm{L}$ caused noticeable increase in tubers firmness, dry matter, starch, acidity and ascorbic acid contents. Meanwhile, soluble solids content, total sugars, weight loss, decay and sprouting percent decreased during storage as compared with the other concentrations of jasmonic acid $(0.001$ or $0.1 \mathrm{mM} \mathrm{JA} / \mathrm{L})$ and the untreated tubers. Additionally, the storage and shelf life of tubers have been extended significantly with $0.01 \mathrm{mM} \mathrm{JA} / \mathrm{L}$ dips during cold storage or ambient temperature at $25 \pm 2^{\circ} \mathrm{C}$ and $75-80 \% \mathrm{RH}$
\end{abstract}

Key words: Jasmonic acid, Chlorpropham, Postharvest, Storability, Potato.

\section{INTRODUCTION}

Potato (Solanum tuberosum L.) is one of the unique and most potential crops having high productivity, supplementing major food requirement in the world (Ross, 1986). It ranks as the world's fourth most important crop, after wheat, rice and maize because of its' great yield potential and high nutritive value (Ross, 1986). It is expected that annually about $376,826,967$ tonnes of potatoes are produced worldwide, from a total area of 19,246,462 hectares, whereas, in Egypt, it reaches $5,029,022$ tonnes from a total area of 184,592 hectares. While, in Yemen the amount of potatoes produced reaches 294,608 tonnes from a total area of 22,816 hectares (FAO, 2016).

Approximately $70 \%$ of the potato crop is placed under medium-long-term storage to meet the demands of consumers and processors (Suttle, 2004). Potatoes deteriorate rapidly during handling and storage due to poor postharvest handling leading to huge losses (Olsen et al., 2006). Sprouting, weight loss, rotting and low temperature sweetening are the major problems occurring during storage. Annual postharvest losses in the US are estimated to about $10-15 \%$ of the harvested crop, and it can reach as high as 30\% (Suttle, 2004). Also, potato postharvest losses in Asia are estimated at 23-27\% (FAO, 2009). Therefore, the extension of storage life and the reduction in post storage loss by postharvest treatments would help to ensure a steadier supply and stabilize the product prices. They added that however, the currently applied methods for long term storage are not adequate to control the deterioration as approximately $50 \%$ of the product is lost in a few months of storage (Rezaee et al., 2011).

Sprouting is a major cause of losses in stored potatoes where it reduces the number of marketable potatoes and intense evaporation of water from sprout surfaces, thus reduce the weight of the remaining tubers (Afek and Warshavsky, 1998). Nevertheless, for producers and processors of chips and fry stock, suppression of sprout growth during storage is absolutely necessary to maintain market quality of the processed products (Suttle, 2008).

There are two main methods of keeping potatoes free of sprouting and fungi infection during storage; the first is storing at low temperature (2$4^{\circ} \mathrm{C}$ ) and the second is by using chemical sprout and fungi suppressants (Prange et al., 1997). Cooltemperature storage is unsuitable for most 
processing potatoes, it cause the degradation of starch to reducing sugar (glucose and fructose). Thus, it is problematic for the potato processing industry, where high sugar levels cause unfavorable browning of chips and fries and dehydrated potato products as reducing sugars react with proteins during heating to produce dark colors (Nourian et al., 2003), and then this reduces their quality (Rastovski, 1987).

The exogenous application of certain plant agrochemicals regulators would offer an economical and safer alternative to control diseases and maintain the dormant sprout of potato tubers. This strategy may provide a commercially viable and environmentally friendly alternative to existing disease control methods. This natural mechanism can be exploited with the application of chemicals such chlorpropham and jasmonic acid, which were evident to have potential for control of postharvest disease and sprout (Tian et al., 2002).

Chlorpropham (CIPC), is one of the carbamate class of compounds (isopropyl-n-3- chlorophenyl). It is the most used and effective sprout inhibitor on potato. It has been in use for more than 50 years (Paul, et al. 2016). The efficacy of CIPC as a sprout suppressant on potatoes especially when stored at 8$12^{\circ} \mathrm{C}$ was documented by many researches (Blenkinsop et al. 2002; Ezekiel et al. 2005; Mehta et al. 2010).

Jasmonate (JA) and its derivates are lipid-based hormone signals that regulate a wide range of processes in plants. Yao and Tian (2005) indicated that methyl jasmonate are endogenous plant substances that play key roles in plant growth and development, and in responses to environmental stresses. Exposing potato tubers to a jasmonate or jasmonate related compound are considered a way for inhibiting sprouting of tubers and maintaining or improving their processing quality (Lulai et. al. 1995).

At present, the most prevalent long-term (6 to 9 months) storage method for potatoes is at temperature of $8-12{ }^{\circ} \mathrm{C}(85-90 \% \mathrm{RH})$ along with the use of JA and/or CIPC as sprout suppressant (Paul, et al. 2016). Successful long-term storage of potatoes for processing and fresh market requires use of sprout in combination with proper storage management.

Information's concerning the effects of postharvest application of chemicals such as chlorpropham and jasmonic acid on potato tubers quality and storability are scant. Accordingly, the scope of the present study is to investigate the influence of chlorpropham, jasmonic acid and their interactions on sprouting, physical and chemical characteristics of potato tubers stored under cold storage.

\section{MATERIALS AND METHODS}

The present study was carried out during the summer season of 2017, at the postharvest center, faculty of agriculture, Alexandria University. The Potato tubers (cv. Diamant) were harvested at its commercial maturity stage from a private farm at Kom Hamada Behira Governorate, Egypt. The selection of tubers were based on the size (medium weight tubers approximately 100-150 gm), the absence of physical injuries, mechanical damage and disease infection. Tubers were packed in net plastic boxes (15 kg/ box) and surface-disinfected with $2 \%$ sodium hypochlorite for 2-4 minutes and then rinsed with tap water and air-dried. The dried tubers were immersed in solutions contains different concentrations of chlorpropham; $0,50,75$ and 100 ppm and jasmonic acid; 0, 0.001, 0.01 and 0.1 $\mathrm{mM} / \mathrm{L}$ either alone or in combinations for 20 minutes. Thereafter, tubers were dried and cured in dark for one week at $20^{\circ} \mathrm{C}$ and $75 \% \mathrm{RH}$. The total number of the treatments combinations were $(4 \times 4$ $=16$ treatments). After curing, the tubers were placed in the dark cold storage room for long-term storage (140 days) at $\left(10 \pm 1^{\circ} \mathrm{C}\right)$ and $85 \pm 5 \%$ relative humidity $(\mathrm{RH})$ to evaluate their influence on physico-chemical characters of potato tubers. Additionally, storability of tubers weight loss, sprouting, decay, and marketable tubers were estimated after removal from cold storage and kept at room temperature $\left(24 \pm 1^{\circ} \mathrm{C}\right)$ for 15 days (ambient temperature). A random sample of potato tubers were selected to determine physico-chemical characters before storage period (initial storage day) and after 140 days during cold storage.

The experimental layout was a split-plots system in a Complete Randomized Design with three replicates. The concentrations of chlorpropham and jasmonic acid distributed in the main and sub plots, orderly. The experimental unit were represent by 16 boxes ( $15 \mathrm{~kg}$ each).

\section{DATA RECORDED}

\section{Physical and Chemical Characters}

A random sample of tubers from each experimental unit after 140 days of storage was taken to measure the following physico-chemical characters; firmness $\left(\mathrm{kg} / \mathrm{cm}^{2}\right)$, dry matter (\%), soluble solid content, starch (\%), titratable acidity, ascorbic acid (mg/100 $\mathrm{g}$ fresh tuber) and total sugars $(\%)$.

\section{Storability of Potato Tubers}

The physiological weight loss (PWL) was calculated from each treatment after 140 days of storage. The difference between initial and final weight of the tubers was considered as total weight loss during the storage interval and calculated as percentage on a fresh weight basis according to the standard method of A.O.A.C (1994). The loss in 
weight was calculated and expressed as a percent using the following formula:

Weight loss $(\%)=\{$ (Initial weight - Weight at specific interval) / Initial weight $\}$ x 100.

The weight loss percent was, also, calculated after tubers kept at room temperature for 15 days for estimated shelf life.

The number of sprouted tubers was recorded after 140 days of storage as well as after tubers kept at room temperature for 15 days. The sprouting percentage of treated and untreated tubers were calculated using the following formula:

Sprouting $(\%)=$ (number of sprouted tubers $/$ initial number of all tubers) x 100 .

The number of decayed tubers was recorded after 140 days of cold storage and after removing from cold storage and kept at room temperature for 15 days then it was calculated according to the following formula:

Decay $(\%)=($ the number of decayed tubers / initial number of all tubers) $x 100$.

At the end of experiments the percent of marketable tubers were calculated by separating the rotted and sprouted tubers and recorded weight of healthy tubers. The recovery of marketable tubers were calculated by using the following formula:

Marketable tubers $\%=($ Weight of healthy tubers $/$ Initial weight of tubers stored) x 100 .

All obtained data were statistically analyzed according the design using Co-Stat Software and the Revised L.S.D. test at 0.05 level was used to compare the differences among the means of the various treatment combinations, as illustrated by Snedecor and Cochran (1980).

\section{RESULTS AND DISCUSSION}

\section{Physical and Chemical Characters}

Results of Table (1), displayed that potato tubers soaked in chlorpropham at the rate of $75 \mathrm{ppm}$ led to increase the mean values of tuber firmness, dry matter content and starch percentage compared to the low rate of CIPC. The highest values of firmness, dry matter, starch, titratable acidity and vitamin $\mathrm{C}$ content of potato tubers were obtained from the application of $75 \mathrm{ppm}$ chlorpropham. Nevertheless, this application gave the lowest mean values of soluble solid content (SSC) and total sugars.

This finding is an agreement of earlier finding of Mohajan et al. (2008), Mehta et al. (2010) and Gautam et al. (2013). They stated that the postharvest treatment with CIPC has positive role to increase processing quality parameters as low total sugar and high dry matter content. The application of CIPC at a dose of $20 \mathrm{mg} \mathrm{kg}^{-1}$ can extend the storage life of potatoes by inhabiting sprout growth, maintaining tissue turgor and reducing total storage losses (Mehta et al. 2011). The dry matter content of Diamant variety was relatively increase as a result of postharvest treating potato tubers with CIPC (Lahmer, 2018)

Results presented in Table (1) clarified the presence of some significant differences on firmness, dry matter, SSC, starch, titratable acidity and total sugars of potato tubers stored for 140 days as a result of using jasmonic acid at the rate of 0.01 and $0.1 \mathrm{mM} / \mathrm{L}$. Raising JA concentration up to 0.01 $\mathrm{mM} / \mathrm{L}$ was associated with significant increase on tuber firmness, dry matter and starch percentage as well as titratable acidity.

Table 1: Effect of chlorpropham and jasmonic acid concentrations on some physical and chemical characteristics of potato tubers after 140 days of cold storage.

\begin{tabular}{|c|c|c|c|c|c|c|c|}
\hline Treatments & $\begin{array}{c}\text { Firmness } \\
(\mathrm{kg} / \mathrm{cm} 2)\end{array}$ & $\begin{array}{c}\text { Dry } \\
\text { matter } \\
(\%)\end{array}$ & $\begin{array}{l}\text { SSC } \\
(\%)\end{array}$ & $\begin{array}{c}\text { Starch } \\
(\%)\end{array}$ & $\begin{array}{c}\text { Acidity } \\
(\%)\end{array}$ & $\begin{array}{c}\mathrm{V} . \mathrm{C} \\
\mathrm{mg} / 100 \\
\mathrm{ml} \mathrm{j} .\end{array}$ & $\begin{array}{c}\text { Total } \\
\text { Sugars } \\
(\%) \\
\end{array}$ \\
\hline \multicolumn{8}{|l|}{$\begin{array}{l}\text { CIPC conc. } \\
(\mathrm{ppm})\end{array}$} \\
\hline 0 & $5.68 \mathrm{C}$ & $23.21 \mathrm{AB}$ & $6.77 \mathrm{~A}$ & $16.69 \mathrm{AB}$ & $0.35 \mathrm{BC}$ & $5.03 \mathrm{AB}$ & $5.89 \mathrm{~A}$ \\
\hline 50 & $5.55 \mathrm{D}$ & $23.11 \mathrm{~B}$ & $6.86 \mathrm{~A}$ & $16.60 \mathrm{~B}$ & $0.34 \mathrm{C}$ & $4.84 \mathrm{AB}$ & $5.97 \mathrm{~A}$ \\
\hline 75 & $5.86 \mathrm{~A}$ & $23.33 \mathrm{~A}$ & $6.17 \mathrm{C}$ & $16.79 \mathrm{~A}$ & $0.39 \mathrm{~A}$ & $5.44 \mathrm{~A}$ & $5.37 \mathrm{C}$ \\
\hline 100 & $5.76 \mathrm{~B}$ & $23.15 \mathrm{AB}$ & $6.48 \mathrm{~B}$ & $16.63 \mathrm{AB}$ & $0.36 \mathrm{~B}$ & $4.72 \mathrm{~B}$ & $5.64 \mathrm{~B}$ \\
\hline \multicolumn{8}{|l|}{$\begin{array}{l}\text { JA conc. } \\
(\mathrm{mM} / \mathrm{L})\end{array}$} \\
\hline 0 & $5.60 \mathrm{C}$ & $23.02 \mathrm{C}$ & $6.88 \mathrm{~A}$ & $16.52 \mathrm{C}$ & $0.34 \mathrm{C}$ & $4.81 \mathrm{~A}$ & $5.99 \mathrm{~A}$ \\
\hline 0.001 & $5.52 \mathrm{C}$ & $23.00 \mathrm{C}$ & $6.92 \mathrm{~A}$ & $16.50 \mathrm{C}$ & $0.33 \mathrm{C}$ & $5.09 \mathrm{~A}$ & $6.02 \mathrm{~A}$ \\
\hline 0.01 & $5.99 \mathrm{~A}$ & $23.53 \mathrm{~A}$ & $5.99 \mathrm{C}$ & $16.97 \mathrm{~A}$ & $0.41 \mathrm{~A}$ & $5.04 \mathrm{~A}$ & $5.22 \mathrm{C}$ \\
\hline 0.1 & $5.73 \mathrm{~B}$ & $23.25 \mathrm{~B}$ & $6.48 \mathrm{~B}$ & 16.72 B & $0.37 \mathrm{~B}$ & $5.09 \mathrm{~A}$ & $5.64 \mathrm{~B}$ \\
\hline Initial value & 6.29 & 25.89 & 5.30 & 19.07 & 0.53 & 8.52 & 4.61 \\
\hline
\end{tabular}

* Values having the same alphabetical letter (s) in common, within a particular group of means in each character, do not significantly differ, using Revised L.S.D. test at 0.05 level. 
However total sugar content of tubers tended to decrease with increasing the rate of JA up to 0.01 or $0.1 \mathrm{mM} / \mathrm{L}$, respectively. Vitamin $\mathrm{C}$ content of tubers did not significantly affected by treating tubers with any concentration of jasmonic acid.

The decrease in total sugar content matching with those reported by Lulai et al (1995), who indicated that melanization which occurs during frying may be controlled by exposure potato tubers to an effective amount of jasmonate or jasmonate related compounds.

The influence of the interaction effects between chlorpropham and jasmonic acid concentrations on firmness of stored tubers was significant (Table 2). The interactive treatment of jasmonic acid at the rate of $0.01 \mathrm{mM} / \mathrm{L}$ at any concentration of chlorpropham gave the highest mean values of firmness. The comparisons among the sixteen interactive treatments, generally, indicated that the combined treatment between jasmonic acid $(0.01 \mathrm{mM} \mathrm{JA} / \mathrm{L})$ plus any concentration of chlorpropham resulted in the highest mean values of potato tuber dry matter and starch content. Nevertheless, the interactions between the untreated tubers with chlorpropham coupled with the rate of $0.001 \mathrm{mM} \mathrm{JA} / \mathrm{L}$ showed the highest mean values of tuber soluble solid content under the conditions of cold storage.

The results listed in Table (2), also, documented that titratable acidity of potato tubers did not significantly affected by the combinations between chlorpropham and jasmonic acid after 140 days of storing in cold storage. Vitamin $\mathrm{C}$ content of potato tubers showed the highest values by treating potato tubers after harvest with the combination solutions of $0.001 \mathrm{mM} \mathrm{JA} / \mathrm{L}$ plus chlorpropham at rate of 75 ppm.

As for the total sugars of potato tubers for 140 days of cold storage, the comparison among the means indicated that the highest mean values appeared to be those of either zero or $0.001 \mathrm{mM}$ $\mathrm{JA} / \mathrm{L}$ coupled with the untreated tubers of chlorpropham.

The obtained results of the interaction effects of the two studied factors on the physiochemical characters of potato tubers may be due to the effect of the individual factors; CIPC and JA as previously mentioned.

\section{Storability of Potato Tubers}

The results shown in Table (3) displayed that, soaking potato tubers into $75 \mathrm{ppm}$ CIPC resulted in decreasing the tubers weight loss, sprouted and decayed percent and increasing marketable tuber (\%). as compared with those of 50, $100 \mathrm{ppm}$ CIPC and the untreated control treatment. Thus, the marketable tubers percentages seemed to have the best result by using the concentration of $75 \mathrm{ppm}$ CIPC.

Table 2: Interaction effects between chlorpropham and jasmonic acid concentrations on some physical and chemical characteristics of potato tubers after 140 days of cold storage.

\begin{tabular}{|c|c|c|c|c|c|c|c|c|}
\hline Treatments & cters & $\begin{array}{l}\text { Firmness } \\
(\mathrm{kg} / \mathrm{cm} 2)\end{array}$ & $\begin{array}{c}\text { Dry } \\
\text { matter } \\
(\%)\end{array}$ & $\begin{array}{l}\text { SSC } \\
(\%)\end{array}$ & $\begin{array}{c}\text { Starch } \\
(\%)\end{array}$ & $\begin{array}{l}\text { Acidity } \\
(\%)\end{array}$ & $\begin{array}{c}\text { V.C } \\
\text { mg/100 } \\
\text { ml j. }\end{array}$ & $\begin{array}{l}\text { Total } \\
\text { Sugars } \\
(\%)\end{array}$ \\
\hline $\begin{array}{c}\text { CIPC conc. } \\
(\mathbf{p p m})\end{array}$ & $\begin{array}{l}\text { JA conc. } \\
(\mathrm{mM} / \mathrm{L})\end{array}$ & & & & & & & \\
\hline \multirow{4}{*}{0} & 0 & $5.53 \mathrm{hi}$ & $22.78 \mathrm{f}$ & $7.27 \mathrm{a}$ & $16.30 \mathrm{f}$ & $0.33 \mathrm{a}$ & $4.63 \mathrm{abc}$ & $6.33 \mathrm{a}$ \\
\hline & 0.001 & $5.43 \mathrm{ij}$ & $23.04 \mathrm{def}$ & $7.37 \mathrm{a}$ & $16.53 \mathrm{def}$ & $0.32 \mathrm{a}$ & $5.24 \mathrm{abc}$ & $6.41 \mathrm{a}$ \\
\hline & 0.01 & $6.01 \mathrm{a}$ & $23.60 \mathrm{a}$ & $5.90 \mathrm{f}$ & $17.03 \mathrm{a}$ & $0.41 \mathrm{a}$ & $4.91 \mathrm{abc}$ & $5.14 \mathrm{f}$ \\
\hline & 0.1 & $5.74 \mathrm{c}-\mathrm{f}$ & $23.43 \mathrm{abc}$ & $6.53 \mathrm{~b}-\mathrm{e}$ & $16.88 \mathrm{abc}$ & $0.36 \mathrm{a}$ & $5.32 \mathrm{abc}$ & $5.69 \mathrm{~b}-\mathrm{e}$ \\
\hline \multirow{4}{*}{50} & 0 & $5.35 \mathrm{jk}$ & $22.87 \mathrm{f}$ & $7.40 \mathrm{a}$ & $16.38 \mathrm{f}$ & $0.30 \mathrm{a}$ & $4.41 \mathrm{bc}$ & $6.44 \mathrm{a}$ \\
\hline & 0.001 & $5.29 \mathrm{k}$ & $22.90 \mathrm{f}$ & $7.23 \mathrm{a}$ & $16.41 \mathrm{f}$ & $0.31 \mathrm{a}$ & $5.32 \mathrm{abc}$ & $6.30 \mathrm{a}$ \\
\hline & 0.01 & $5.92 \mathrm{ab}$ & $23.59 \mathrm{a}$ & $6.17 \mathrm{ef}$ & $17.02 \mathrm{a}$ & $0.40 \mathrm{a}$ & $4.70 \mathrm{abc}$ & $5.37 \mathrm{ef}$ \\
\hline & 0.1 & $5.63 \mathrm{fgh}$ & $23.09 \mathrm{c}-\mathrm{f}$ & $6.63 \mathrm{bc}$ & $16.58 \mathrm{c}-\mathrm{f}$ & $0.36 \mathrm{a}$ & $4.91 \mathrm{abc}$ & $5.78 \mathrm{bc}$ \\
\hline \multirow{4}{*}{75} & 0 & $5.85 \mathrm{bc}$ & $23.30 \mathrm{a}-\mathrm{e}$ & $6.23 c-f$ & $16.77 \mathrm{a}-\mathrm{e}$ & $0.38 \mathrm{a}$ & $4.95 \mathrm{abc}$ & $5.43 \mathrm{c}-\mathrm{f}$ \\
\hline & 0.001 & $5.77 \mathrm{cde}$ & $23.15 b-f$ & $6.27 \mathrm{c}-\mathrm{f}$ & $16.63 \mathrm{~b}-\mathrm{f}$ & $0.36 \mathrm{a}$ & $5.73 \mathrm{a}$ & $5.46 \mathrm{c}-\mathrm{f}$ \\
\hline & 0.01 & $6.00 \mathrm{a}$ & $23.52 \mathrm{ab}$ & $5.97 \mathrm{f}$ & $16.96 \mathrm{ab}$ & $0.42 \mathrm{a}$ & $5.50 \mathrm{ab}$ & $5.20 \mathrm{f}$ \\
\hline & 0.1 & $5.80 \mathrm{~cd}$ & $23.35 \mathrm{a}-\mathrm{d}$ & $6.20 \mathrm{def}$ & $16.80 \mathrm{a}-\mathrm{d}$ & $0.40 \mathrm{a}$ & $5.57 \mathrm{ab}$ & $5.40 \mathrm{def}$ \\
\hline \multirow{4}{*}{100} & 0 & $5.68 \mathrm{efg}$ & $23.13 \mathrm{c}-\mathrm{f}$ & $6.60 \mathrm{bcd}$ & $16.62 \mathrm{c}-\mathrm{f}$ & $0.36 \mathrm{a}$ & $5.24 \mathrm{abc}$ & $5.75 \mathrm{bcd}$ \\
\hline & 0.001 & $5.60 \mathrm{gh}$ & $22.92 \mathrm{ef}$ & $6.80 \mathrm{~b}$ & 16.42 ef & $0.33 \mathrm{a}$ & $4.05 \mathrm{c}$ & $5.92 \mathrm{~b}$ \\
\hline & 0.01 & $6.03 \mathrm{a}$ & $23.40 \mathrm{a}-\mathrm{d}$ & $5.93 \mathrm{f}$ & $16.86 \mathrm{a}-\mathrm{d}$ & $0.41 \mathrm{a}$ & $5.04 \mathrm{abc}$ & $5.17 \mathrm{f}$ \\
\hline & 0.1 & $5.73 \mathrm{def}$ & $23.14 \mathrm{~b}-\mathrm{f}$ & $6.57 \mathrm{~b}-\mathrm{e}$ & $16.62 \mathrm{~b}-\mathrm{f}$ & $0.35 \mathrm{a}$ & $4.54 \mathrm{abc}$ & $5.72 \mathrm{~b}-\mathrm{e}$ \\
\hline Initial value & & 6.29 & 25.89 & 5.30 & 19.07 & 0.53 & 8.52 & 4.61 \\
\hline
\end{tabular}

* Values having the same alphabetical letter (s) in common, within a particular group of means in each character, do not significantly differ, using Revised L.S.D. test at 0.05 level. 
Table 3: Effect of chlorpropham and jasmonic acid concentrations on storability of potato tubers after 140 days of cold storage.

\begin{tabular}{|c|c|c|c|c|}
\hline Treatments & $\begin{array}{c}\text { Weight loss } \\
(\%) \\
\end{array}$ & $\begin{array}{c}\text { Sprouted } \\
(\%) \\
\end{array}$ & $\begin{array}{c}\text { Decayed } \\
(\%) \\
\end{array}$ & $\begin{array}{c}\text { Marketable tubers } \\
(\%) \\
\end{array}$ \\
\hline \multicolumn{5}{|l|}{$\begin{array}{l}\text { CIPC conc. } \\
(\mathrm{ppm})\end{array}$} \\
\hline 0 & $3.27 \mathrm{~A}$ & $20.17 \mathrm{AB}$ & $2.83 \mathrm{~A}$ & $77.00 \mathrm{C}$ \\
\hline 50 & $3.35 \mathrm{~A}$ & $21.83 \mathrm{~A}$ & $2.00 \mathrm{AB}$ & $76.17 \mathrm{C}$ \\
\hline 75 & $2.65 \mathrm{C}$ & $11.00 \mathrm{C}$ & $0.67 \mathrm{~B}$ & $88.33 \mathrm{~A}$ \\
\hline 100 & $2.95 \mathrm{~B}$ & $18.67 \mathrm{~B}$ & $1.67 \mathrm{AB}$ & $79.67 \mathrm{~B}$ \\
\hline \multicolumn{5}{|l|}{$\begin{array}{l}\text { JA conc. } \\
(\mathrm{mM} / \mathrm{L})\end{array}$} \\
\hline 0 & $3.30 \mathrm{~A}$ & $23.00 \mathrm{~A}$ & $2.00 \mathrm{AB}$ & $75.00 \mathrm{C}$ \\
\hline 0.001 & $3.21 \mathrm{~A}$ & $22.00 \mathrm{~A}$ & $2.67 \mathrm{~A}$ & $75.33 \mathrm{C}$ \\
\hline 0.01 & $2.69 \mathrm{C}$ & $9.83 \mathrm{C}$ & $0.67 \mathrm{~B}$ & $89.50 \mathrm{~A}$ \\
\hline 0.1 & $3.03 \mathrm{~B}$ & $16.83 \mathrm{~B}$ & $1.83 \mathrm{AB}$ & $81.33 \mathrm{~B}$ \\
\hline
\end{tabular}

* Values having the same alphabetical letter (s) in common, within a particular group of means in each character, do not significantly differ, using Revised L.S.D. test at 0.05 level.

As for the effect of jasmonic acid on storability of potato tubers stored for 140 days expressed as weight loss, sprouted and decayed percentage, the results in Table (3) demonstrated that increasing the rate of jasmonic acid up to $0.01 \mathrm{mM} / \mathrm{L}$ gave the lowest percentage of weight loss, sprouted and decayed tubers. Meanwhile the highest significant increases on marketable tubers was obtained with the rate of $0.01 \mathrm{mM} / \mathrm{L}$.

Similar results was reported by Ezekiel et al. (2005) and (2002) who exhibited that the application of CIPC at 40 and $60 \mathrm{ml} /$ tone of potatoes significantly reduced the weight loss of tubers stored after 180 days at $12^{\circ} \mathrm{C}$. The weight loss $(\%)$ in potato during the postharvest storage is associated with moisture loss due to evapotranspiration and dry matter loss due to respiration and sprouting (Tester et al. 2005). Decreasing sprouted and decayed percent by using sprout-preventing chemicals was also reported by Lulai et al. (1995) and Platonova et al. (2010) as a result of using jasmonate for inhabiting sprouting of tubers and maintaining their processing quality. The beneficial effects of using CIPC to control tuber dormancy and prevent sprouting was earlier reported by many researchers (Corsini et al. 1979; Mondy, 1993; Baloch, 1999; Pringle et al. 2009 and Barbara et al. 2011).

Inhibition of potato sprouting during storage with using sprout-preventing chemicals probably delays metabolic changes in potato tubers (TeperBamnolker et al. 2010). CIPC inhibits sprout development by interfering with cell division through the specific inhibition of mitosis (Nurit et al. 1989) and is effective at maintaining long-term sprout control (Wilshire and Cobb, 1996).
The role of JA for preventing tuber sprouting during storage explained by Platonova et al. (2010) as JA changed the ultrastructure of plasmalemma and plastid apparatus of eye meristematic cells and functioned together with other hormonal compounds.

The interaction effects between CIPC and JA on weight loss, sprouted and decayed percentage of potato tubers are presented in Table (4). The maximum values of weight loss, sprouted and decayed tubers were obtained by the combination treatment of untreated tubers with CIPC and JA. The minimum percentage of weight loss and decayed tubers obtained by the interactive treatment between $0.01 \mathrm{mM} \mathrm{JA} / \mathrm{L}$ coupled with the concentration of $100 \mathrm{ppm}$ of CIPC. Nevertheless, the combined treatment of $0.01 \mathrm{mM} \mathrm{JA} / \mathrm{L}$ plus 75 ppm of CIPC tended to give the lowest significant value of sprouted tubers. Furthermore, the highest mean values of marketable tubers were obtained from the treatment combination of $0.1 \mathrm{mM} \mathrm{JA} / \mathrm{L}$ plus 75 ppm of chlorpropham.

The results presented in Table (5) list the effect of various CIPC and JA concentrations on the storability of potato tubers held at room temperature for 15 days after long-term storing of cold storage (140 days). The obtained results showed that the minimum mean values of weight loss, sprouted and decayed tubers were recorded by the concentration of $75 \mathrm{ppm}$ CIPC or $0.01 \mathrm{mM} \mathrm{JA} / \mathrm{L}$. The results, also, revealed that using CIPC at rate of $75 \mathrm{ppm}$ or $\mathrm{JA}$ at the rate of $0.01 \mathrm{mM} \mathrm{JA} / \mathrm{L}$ led to the highly significant value of marketable tubers. 
The results listed in Table (6), illustrated that weight loss, sprouted, decayed tubers and marketable tubers were significantly affected by the combination treatments of CIPC and JA. The untreated tubers gave the maximum percentage of weight loss, sprouted and decayed tubers. The combined treatment of $0.01 \mathrm{mM} \mathrm{JA} / \mathrm{L}$ plus any concentration of CIPC gave the maximum marketable tubers percentage.

Table 4: Interaction effects between chlorpropham and jasmonic acid concentrations on storability of potato tubers after 140 days of cold storage.

\begin{tabular}{|c|c|c|c|c|c|}
\hline \multicolumn{2}{|c|}{ Treatments } & $\begin{array}{c}\text { Weight loss } \\
(\%) \\
\end{array}$ & $\begin{array}{c}\text { Sprouted } \\
(\%) \\
\end{array}$ & $\begin{array}{c}\text { Decayed } \\
(\%) \\
\end{array}$ & $\begin{array}{c}\text { Marketable tubers } \\
(\%) \\
\end{array}$ \\
\hline $\begin{array}{r}\text { CIPC conc. } \\
(\mathbf{p p m}) \\
\end{array}$ & $\begin{array}{l}\text { JA conc. } \\
(\mathrm{mM} / \mathrm{L})\end{array}$ & & & & \\
\hline \multirow{4}{*}{0} & 0 & $4.02 \mathrm{a}$ & $29.33 \mathrm{a}$ & $5.33 \mathrm{a}$ & $65.33 \mathrm{~h}$ \\
\hline & 0.001 & $3.13 \mathrm{~b}-\mathrm{e}$ & $26.00 \mathrm{a}$ & $2.67 \mathrm{a}-\mathrm{d}$ & $71.33 \mathrm{fg}$ \\
\hline & 0.01 & $2.82 \mathrm{efg}$ & $8.67 \mathrm{f}$ & $1.33 \mathrm{bcd}$ & $90.00 \mathrm{a}$ \\
\hline & 0.1 & $3.12 \mathrm{~b}-\mathrm{e}$ & $16.67 \mathrm{~cd}$ & $2.00 \mathrm{bcd}$ & $81.33 \mathrm{~cd}$ \\
\hline \multirow{4}{*}{50} & 0 & $3.53 b c$ & $29.33 \mathrm{a}$ & $2.00 \mathrm{bcd}$ & $68.67 \mathrm{gh}$ \\
\hline & 0.001 & $3.55 \mathrm{~b}$ & $26.00 \mathrm{a}$ & $4.00 \mathrm{ab}$ & $70.00 \mathrm{~g}$ \\
\hline & 0.01 & $2.90 \mathrm{efg}$ & $10.67 \mathrm{ef}$ & $0.67 \mathrm{~cd}$ & $88.67 \mathrm{ab}$ \\
\hline & 0.1 & $3.43 \mathrm{bcd}$ & $21.33 \mathrm{~b}$ & $1.33 \mathrm{bcd}$ & $77.33 \mathrm{de}$ \\
\hline \multirow{4}{*}{75} & 0 & $2.55 \mathrm{fg}$ & $11.33 \mathrm{ef}$ & $0.00 \mathrm{~d}$ & $88.67 \mathrm{ab}$ \\
\hline & 0.001 & $2.95 \mathrm{ef}$ & $14.00 \mathrm{de}$ & $0.67 \mathrm{~cd}$ & $85.33 \mathrm{bc}$ \\
\hline & 0.01 & $2.60 \mathrm{fg}$ & $8.67 \mathrm{f}$ & $0.67 \mathrm{~cd}$ & $90.67 \mathrm{a}$ \\
\hline & 0.1 & $2.50 \mathrm{fg}$ & $10.00 \mathrm{f}$ & $1.33 \mathrm{bcd}$ & $88.67 \mathrm{ab}$ \\
\hline \multirow{4}{*}{100} & 0 & $3.08 \mathrm{cde}$ & $22.00 \mathrm{~b}$ & $0.67 \mathrm{~cd}$ & $77.33 \mathrm{de}$ \\
\hline & 0.001 & $3.22 \mathrm{~b}-\mathrm{e}$ & $22.00 \mathrm{~b}$ & $3.33 \mathrm{abc}$ & $74.67 \mathrm{ef}$ \\
\hline & 0.01 & $2.45 \mathrm{~g}$ & $11.33 \mathrm{ef}$ & $0.00 \mathrm{~d}$ & $88.67 \mathrm{ab}$ \\
\hline & 0.1 & $3.07 \mathrm{de}$ & $19.33 \mathrm{bc}$ & $2.67 \mathrm{a}-\mathrm{d}$ & $78.00 \mathrm{de}$ \\
\hline
\end{tabular}

* Values having the same alphabetical letter (s) in common, within a particular group of means in each character, do not significantly differ, using Revised L.S.D. test at 0.05 level.

Table 5: Effect of chlorpropham and jasmonic acid concentrations on storability of potato tubers held at room temperature for 15 days after cold storage.

\begin{tabular}{|c|c|c|c|c|}
\hline Treatments & $\begin{array}{c}\text { Weight loss } \\
(\%) \\
\end{array}$ & $\begin{array}{c}\text { Sprouted } \\
(\%) \\
\end{array}$ & $\begin{array}{c}\text { Decayed } \\
(\%) \\
\end{array}$ & $\begin{array}{c}\text { Marketable tubers } \\
(\%) \\
\end{array}$ \\
\hline \multicolumn{5}{|l|}{$\begin{array}{l}\text { CIPC conc. } \\
(\mathrm{ppm})\end{array}$} \\
\hline 0 & $3.67 \mathrm{~A}$ & $23.61 \mathrm{~A}$ & $4.17 \mathrm{~A}$ & $72.22 \mathrm{C}$ \\
\hline 50 & $3.63 \mathrm{~A}$ & $24.44 \mathrm{~A}$ & $3.89 \mathrm{~A}$ & $71.67 \mathrm{C}$ \\
\hline 75 & $3.44 \mathrm{~B}$ & $11.67 \mathrm{C}$ & $0.83 \mathrm{~B}$ & $87.50 \mathrm{~A}$ \\
\hline 100 & $3.62 \mathrm{~B}$ & $17.78 \mathrm{~B}$ & $3.61 \mathrm{~A}$ & $78.61 \mathrm{~B}$ \\
\hline \multicolumn{5}{|l|}{$\begin{array}{l}\text { JA conc. } \\
(\mathrm{mM} / \mathrm{L})\end{array}$} \\
\hline 0 & $3.66 \mathrm{~A}$ & $22.50 \mathrm{~A}$ & $5.00 \mathrm{~A}$ & $72.50 \mathrm{~B}$ \\
\hline 0.001 & $3.71 \mathrm{~A}$ & $23.61 \mathrm{~A}$ & $4.72 \mathrm{~A}$ & $71.67 \mathrm{~B}$ \\
\hline 0.01 & $3.44 \mathrm{C}$ & $11.11 \mathrm{~B}$ & $0.00 \mathrm{C}$ & $88.89 \mathrm{~A}$ \\
\hline 0.1 & $3.56 \mathrm{~B}$ & $20.28 \mathrm{~A}$ & $2.78 \mathrm{~B}$ & $76.94 \mathrm{~B}$ \\
\hline
\end{tabular}


Table 6: Interaction effects between chlorpropham and jasmonic acid concentrations on storability of potato tubers held at room temperature for 15 days after cold storage.

\begin{tabular}{|c|c|c|c|c|c|}
\hline \multicolumn{2}{|l|}{ Treatments } & $\begin{array}{c}\text { Weight loss } \\
(\%) \\
\end{array}$ & $\begin{array}{c}\text { Sprouted } \\
(\%)\end{array}$ & $\begin{array}{c}\text { Decayed } \\
(\%) \\
\end{array}$ & $\begin{array}{c}\text { Marketable tubers } \\
(\%)\end{array}$ \\
\hline $\begin{array}{r}\text { CIPC conc. } \\
(\mathrm{ppm})\end{array}$ & $\begin{array}{l}\text { JA conc. } \\
(\mathrm{mM} / \mathrm{L})\end{array}$ & & & & \\
\hline \multirow{4}{*}{0} & 0 & $3.85 \mathrm{a}$ & $31.11 \mathrm{a}$ & $7.78 \mathrm{a}$ & $61.11 \mathrm{f}$ \\
\hline & 0.001 & $3.73 \mathrm{bc}$ & $30.00 \mathrm{ab}$ & $5.56 \mathrm{abc}$ & $64.44 \mathrm{ef}$ \\
\hline & 0.01 & $3.50 \mathrm{ghi}$ & $12.22 \mathrm{efg}$ & $0.00 \mathrm{e}$ & $87.78 \mathrm{a}$ \\
\hline & 0.1 & $3.60 \mathrm{efg}$ & $21.11 \mathrm{~b}-\mathrm{e}$ & $3.33 \mathrm{~b}-\mathrm{e}$ & $75.56 \mathrm{~cd}$ \\
\hline \multirow{4}{*}{50} & 0 & $3.70 \mathrm{bcd}$ & $28.89 \mathrm{abc}$ & $6.67 \mathrm{ab}$ & $64.44 \mathrm{ef}$ \\
\hline & 0.001 & $3.78 \mathrm{ab}$ & $28.89 \mathrm{abc}$ & $5.56 \mathrm{abc}$ & $65.56 \mathrm{ef}$ \\
\hline & 0.01 & $3.42 \mathrm{ijk}$ & $12.22 \mathrm{efg}$ & $0.00 \mathrm{e}$ & $87.78 \mathrm{a}$ \\
\hline & 0.1 & 3.64 cde & $27.78 \mathrm{a}-\mathrm{d}$ & $3.33 \mathrm{~b}-\mathrm{e}$ & $68.89 \mathrm{def}$ \\
\hline \multirow{4}{*}{75} & 0 & $3.46 \mathrm{hij}$ & $11.11 \mathrm{fg}$ & $2.22 \mathrm{cde}$ & $86.67 \mathrm{ab}$ \\
\hline & 0.001 & $3.57 \mathrm{efg}$ & $14.44 \mathrm{efg}$ & $1.11 \mathrm{de}$ & $84.44 \mathrm{abc}$ \\
\hline & 0.01 & $3.34 \mathrm{k}$ & $8.89 \mathrm{~g}$ & $0.00 \mathrm{e}$ & $91.11 \mathrm{a}$ \\
\hline & 0.1 & $3.38 \mathrm{jk}$ & $12.22 \mathrm{efg}$ & $0.00 \mathrm{e}$ & $87.78 \mathrm{a}$ \\
\hline \multirow{4}{*}{100} & 0 & $3.63 \mathrm{de}$ & $18.89 \mathrm{def}$ & $3.33 \mathrm{~b}-\mathrm{e}$ & $77.78 \mathrm{bcd}$ \\
\hline & 0.001 & $3.74 \mathrm{bc}$ & $21.11 \mathrm{~b}-\mathrm{e}$ & $6.67 \mathrm{ab}$ & $72.22 \mathrm{de}$ \\
\hline & 0.01 & $3.52 \mathrm{fgh}$ & $11.11 \mathrm{fg}$ & $0.00 \mathrm{e}$ & $88.89 \mathrm{a}$ \\
\hline & 0.1 & $3.61 \mathrm{def}$ & $20.00 \mathrm{c}-\mathrm{f}$ & $4.44 \mathrm{a}-\mathrm{d}$ & $75.56 \mathrm{~cd}$ \\
\hline
\end{tabular}

\section{REFERENCES}

Afek, U. and S. Warshavsky 1998. Problems in storage of potatoes in Israel. In: Levy, D. (ed.). Potato in Hot Climate. Israel Agresearch, Journal of the Agricultural Research Organization (in Hebrew, English abstract) Agricultural Research Organization (ARO), The Volcani Center, Israel, Vol. 9: 97-114.

A.O.A.C., 1994. Association of Official Analytical Chemists, Official Methods of Analysis, 16th ed. A.O.A.C.

Baloch, W. A. K. 1999. The distribution and fate of chlorpropham in commercial potato stores. Ph.D. Thesis, Glasgow: University of Glasgow.

Barbara, J., Daniels-Lake, K. Pruski, and R.K. Prange 2011. Using Ethylene Gas and Chlorpropham Potato Sprout Inhibitors Together. Potato Res. 54: 223-236.

Blenkinsop, R.W., L.J. Copp, R.Y. Yada, and A.G. 2002. Marangoni Effect of Chlorpropham (CIPC) on carbohydrate metabolism of potato tubers during storage. Food Res Int. 35: 651655.

Corsini D., G. Stallknecht, W. Sparks 1979. Changes in Chlorpropham residues in stored potatoes. Amer Potato J. 56: 43-50.
Ezekiel, R., A. Mehta, B. Singh, D. Kumar, N.R. Kumar, V. Paul, and M. Das 2005. CIPC [Isopropyl N-(3-chlorophenyl) carbamate] for sprout suppression in potatoes during storage. Shimla: Technical Bulletin No. 69, Central Potato Research Institute (CPRI).

Ezekiel, R., P.S. Dahiya, and G.S. Shekhawat 2002. Traditional methods of potato storage in the Malwa region of Madhya Pradesh. Shimla: Technical Bulletin No. 57, Central Potato Research Institute (CPRI).

FAO, 2009. FAO State Agriculture DATA Agriculture production crop. Primary available.

http://faostat.Fao.org/faostat/collection/subset $=$ agriculture.

FAO, 2016. FAO State Agriculture DATA Agriculture production crop. http://faostat.Fao.org/faostat/collection/subset $=$ agriculture.

Gautam, I.P., M.D. Sharma, B.B. Khatri, R.B. Thapa, and K. Shrestha. 2013. Storability and chips quality of chemical treated potatoes under ordinary condition. J. Basic and Applied Sci. 9: 1. 
Lahmer, R. A. 2018. Effect of storage period at cold storage on some physical and chemical properties of potato tuber prepared for processing. 4th International Conference on Biotechnology Applications in Agriculture (ICBAA), 4-7 April 2018, Hurghada, Egypt. Organized by Faculty of Agriculture, Benha University, Egypt (Website: http://www.icbaa.bu.edu.eg).

Lulai, E.C., P.H. Orr, and M.T. Glynn 1995. Natural suppression of sprouting in stored potatoes using jasmonates. United States Patent. $\mathbf{5 , 4 3 6 , 2 2 6 .}$

Mahajan, B.V.C., A.S. Dhatt, K.S. Sandhu and A. Garg, 2008. Effect of CIPC (isopropyl-N (3 chlorophenyl) carbamate) on storage and processing quality of potato. J. Food Agric. Environ., 6(1): 34-38.

Mehta, A., B. Singh, and R. Ezekiel 2011. Effect of CIPC treatment on keeping and processing attributes during short term storage. Indian J. Plant Physiol., Vol. 16, No. 1, (N.S.) pp. 8592.

Mehta, A., B. Singh, R. Ezekiel, and D. Kumar 2010. Effect of CIPC on sprout inhibition and processing quality of potatoes stored under traditional storage system. Indian Potato Res. 53: $1-15$.

Mondy N. L. 1993. Effect of packaging material on the quality of potatoes treated with isopropyl N-(3- chlorophenl) carbamate (CIPC). J. Food Quality 16, 393-403.

Nourian, F., H.S. Ramaswamy, and A.C. Kushalappa 2003. Kinetics of quality change associated with the potatoes stored at different temperatures. LebensmittelWissenchaft und-Technologie, 36: 49-65.

Nurit, F., E. G. De Melo, P. Ravanel, and T. Michel 1989. Specific inhibition of mitosis in cell suspension cultures by a $\mathrm{N}$ phenylcarbamate series. Pesticide Biochemistry and Physiology 35(3):203-210.

Olsen, N., J. Miller, and P. Nolte 2006. Diagnosis \& Management of Potato Storage Diseases. Published July University of Idah .

Paul, V., R. Ezekiel, and R. Pandey 2016. Sprout suppression on potato: need to look beyond CIPC for more effective and safer alternatives. J Food Sci Technol. 53(1):1-18.

Platonova, T. A., A. S. Evsyunina, and N. P. Korableva 2010. Changes in the Plastid Apparatus of Apical Meristem Cells of Potato Tubers upon Growth Regulation with Jasmonic Acid, Appl. Biochem. Microbiol. vol. 46, pp. 352-358.
Prange, R., W. Kalt, B. Daniels-Lake, C. Liew, J. Walsh, P. Dean, R. Coffin, and R. Page 1997. Alternatives to currently used potato sprout suppressants. Conference Proceedings, Postharvest News and Information 8: 37-41.

Pringle, B., C. Bishop, and R. Clayton 2009. Potatoes Postharvest. CAB International, UK. pp. 427.

Rastovski, A. 1987. Storage losses. In: Rastovski, A. and A. van Es (Eds), Storage of Potatoes: Post-harvest Behavior, Store Design, Storage Practice, Handling. Pudoc, Wageningen, The Netherlands, pp. 177-180.

Rezaee, M., M. Almassi, F.A. Majdabadi, S. Minaei, and M. Khodadadi 2011. Potato Sprout Inhibition and Tuber Quality after Post Harvest Treatment with Gamma Irradiation on Different Dates. J. Agr. Sci. Tech., 13: 829-842.

Ross, H. 1986. Potato Breeding - Problems and Perspectives. J. Plant Breed. Supplement, 13: $1-132$.

Snedecor, G.W. and W.G. Cochran 1980. Statical method, $7^{\text {th }}$ Edn. Ames: Iowa state University Piress. 507 pp.

Suttle, J.C. 2004. Physiological Regulation of Potato Tuber Dormancy. Amer J. of Potato Res., 81:253-262.

Suttle, J.C. 2008. Effects of Synthetic Phenylurea and Nitroguanidine Cytokinins on Dormancy Break and Sprout Growth in Russet Burbank Minitubers. Amer J. of Potato Res., 85 (2): 121-128.

Teper-Bamnolker, P., Dudai, N., Fischer, R., Belausov, E., Zemach, H., Shoseyov, O. \& Eshel, D. 2010. Mint essential oil can induce or inhibit potato sprouting by differential alteration of apical meristem. Planta (Berlin), 232, 179-186.

Tester, R. F., R. Ansell, C. E. Snape, and M. Yusuph 2005. Effect of storage temperatures and annealing conditions on the structure and properties of potato (Solanum tuberosum) starch. Intl. J. Biol. Macromol. 36: 1-8.

Tian, S.P., Q. Fan, Y. Xu, and A.L. Jiang 2002. Effects of calcium on biocontrol activity of yeast antagonists against the postharvest decay fungal pathogen Rhizopus stolonifer. Plant Pathology, 51: 352-358.

Wiltshire, J. J., and A. H. Cobb 1996. A review of the physiology of potato tuber dormancy. Annals Appl. Biol. 129: 553-569.

Yao, H. and S. Tian 2005. Effects of pre-and postharvest application of salicylic acid or methyl jasmonate on inducing disease resistance of sweet cherry fruit in storage. Postharvest Biol. Tech., 35: 253-262. 


\title{
الملخص العربي
}

\section{تأثير المعاملات بحمض الجاسمونيك والكلوربروفام على الإنبات والجودة و القدرة التخزينية}

\section{لارنات البطاطس أثناء التخزين المبرد}

\author{
محمد صالح ضيف الله '، '، فتحي إبراهيم الأدغم'، سناء مرسي العربي'، إبراهيم محمد غنيم'

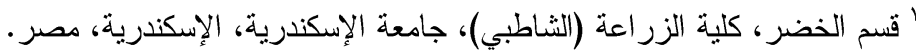

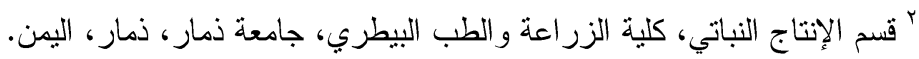

أجريت هذه الدراسة على درنات البطاطس صنف ديامونت، و التي تم حصادها من إحدى مزارع الإنتاج

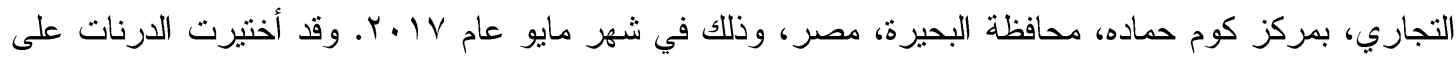

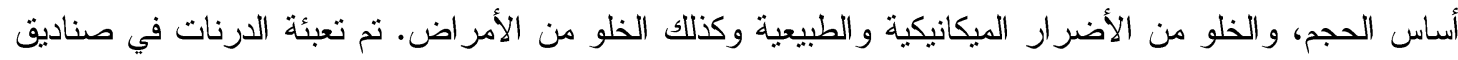

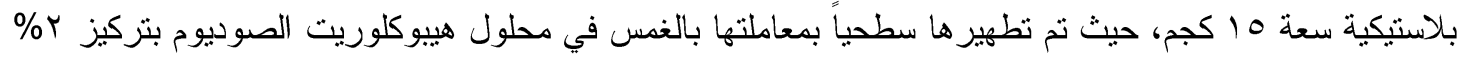

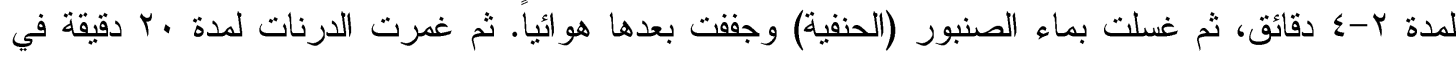

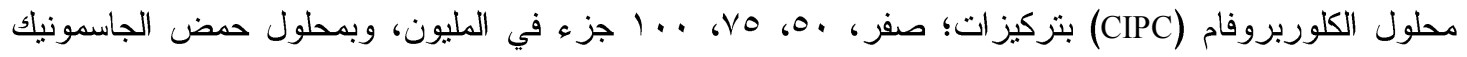

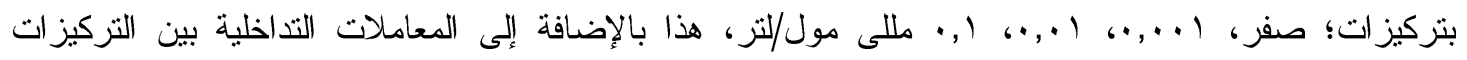

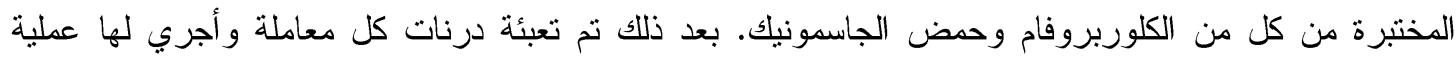

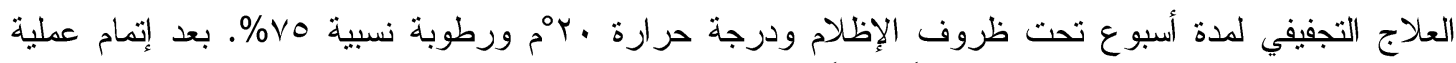

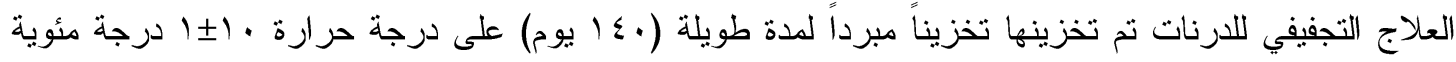

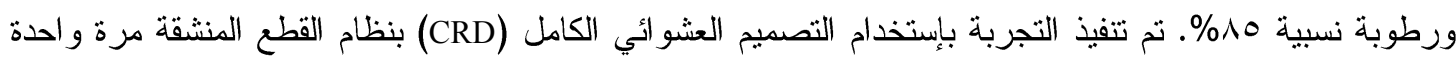
في ثلاثة مكررات، حيث أعتبرت تركيزات الكلوربروفام المعاملة الرئيسية وتركيزات حمض الجاسمونيك المعاملة الثانوية (تحت الرئيسي)، وقد منلت كل معاملة عاملية بصندوق بلاسنيك سعة 10 كجم درنات وذللك في الثلاثة

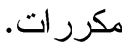

أظهرت النتائج أن معاملة الدرنات السابق تخزينها تخزيناً مبرداً لمدة . ــ يوم بالكلوربروفام، أدت إلى زيادة

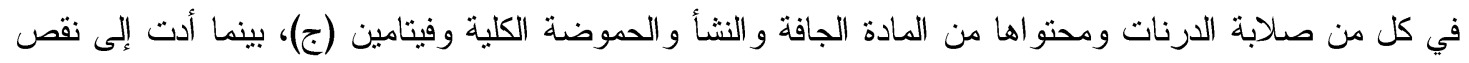

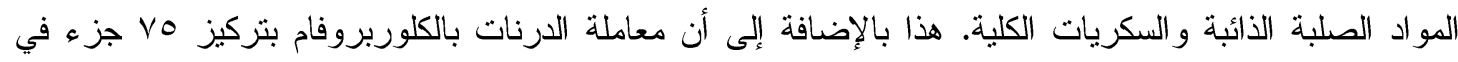

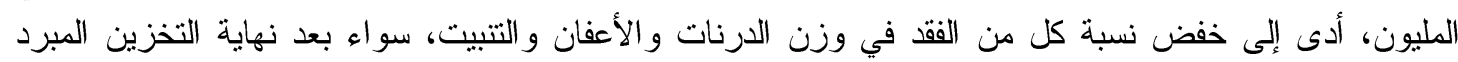

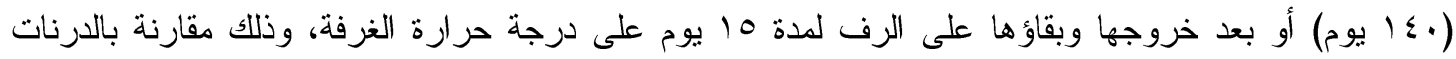

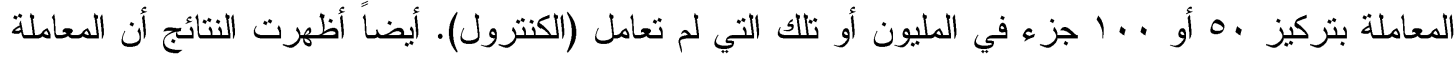

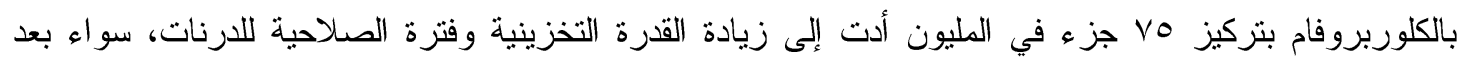

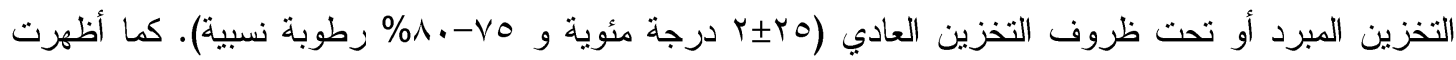

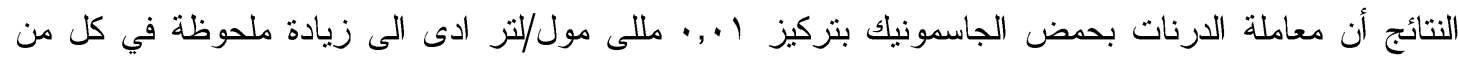

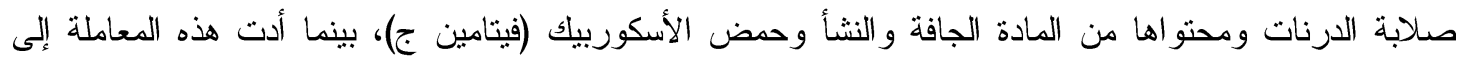

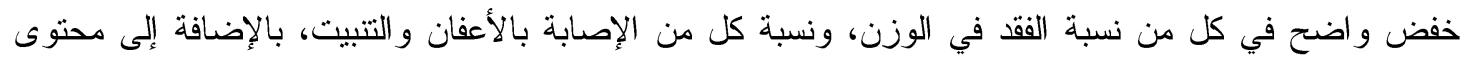

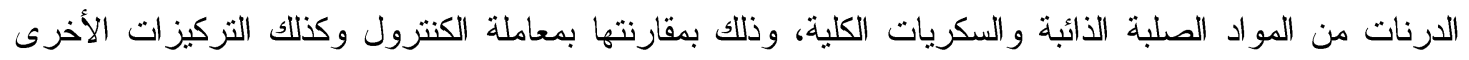

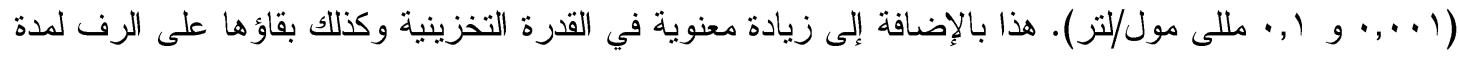

